\title{
ORGANOPLASTICS OF TRIBOTECHNICAL PURPOSE
}

\section{Tomina A.-M. V., Buria O. I.}

\section{INTRODUCTION}

Nowadays, materials scientists are trying to solve one of the urgent problems of modern technology: the search for new effective, profitable and environmentally friendly substitutes for common materials (steel and its alloys, cast iron, babbitt, bronze, etc.) of tribotechnical purpose. Most sliding friction units equipped with standard metal parts fail in 85-90\% of cases during operation due to their insufficient wear resistance, which leads to equipment downtime, and as a result to significant material damage connected with its' downtime and costs for maintenance ${ }^{1}$. The use of polymer composite materials (PCM) based on thermoplastic binders, reinforced with organic fibers (OF) is a promising way to solve this problem due to a combination of such high technical characteristics as strength, corrosion and chemical resistance, low density with relatively low cost of production. According to the researches, organoplastics (OP) in sliding friction units of various equipment (agricultural, automotive, textile, etc.) have proven to be a promising material for tribotechnical purposes ${ }^{2}$.

Thus, plain bearings with OP are characterized by high selflubricating ability (exclusion of lubrication from the process), resistance to fatigue and dynamic loads, erosion, many aggressive environments (acids, petroleum products, etc.), stability at high humidity and temperature. In particular, the use of organoplastics increases the wear resistance of tribological joints of equipment by 1.5 times that leads to an increase in service life and maintenance intervals by 3 times, the term of

${ }^{1}$ Кулагина Г.С., Коробова А.В., Ильичев А.В., Железина Г.Ф. Физические и физико-механические свойства антифрикционного органопластика на основе комбинированного тканого наполнителя и эпоксидного связующего. Труды ВИАМ. 2017. Т. 58. № 10. С. 69-78.

2 Лупкин Б.В., Мамлюк О.В., Драник А.И., Касс А.Л. Влияние технологических параметров процесса сверления композиционных материалов на прочность. Открытые информационные и компьютерные интегрированные технологии. 2016. № 71. С. 125-135. 
preventive maintenance increases by 2 times; the negative impact on the environment reduces, too ${ }^{3}$.

In the context of the above, the development and study of wearresistant OP for tribological joints for modern aviation, automotive and agricultural machinery is an urgent task for modern materials science.

\section{Objects and methods of the researches}

Aromatic polyamide phenylene C-1 was chosen as the polymer matrix, because it arouses a great interest among thermoplastic binders for the creation of fibrous PCM due to the combination of its high thermal and mechanical characteristics. It should be mentioned that phenylone aromatic polyamide contains more than $85 \%$ of amide groups (-CO-NH-) in the main chain; and they are connected with two aromatic rings. Due to that fact it is characterized by dimensional stability (in comparison with aliphatic polyamides), high fatigue strength, fire resistance and ability to withstand significant statistical and dynamic loads under the influence of elevated temperatures (up to $523 \mathrm{~K}$ ), radiation and aggressive environments (dilute and concentrated alkalis, lubricants, gasoline) ${ }^{4}$.

A valuable set of these characteristics has led to the widespread use of polyamides in various areas of machinery. Thus, parts made of phenylone are used as a tribotechnical material that is operated in a wide range of temperatures. Thanks to the high strength, hardness that are saved at high temperatures, phenylone in many cases is a valid replacement for metals.

However, despite the high performance indicators of phenylone, there are circumstances that constrain its widespread use in the manufacture of parts for tribological joints. Thus, aromatic polyamides are characterized mainly by low values of wear resistance (at high loads and sliding speeds), heat conductivity and thermal diffusivity under conditions of friction without lubrication. In addition, various fillers are added to them to improve these characteristics.

${ }^{3}$ Набережна О.О. Розробка та дослідження властивостей самоармованих органопластиків на основі термостійких ароматичних поліамідів : дис. на здобуття вченого ступеня канд. техн. наук : 05.02.01. Луцьк, 2017. 205 с.

Смотрина Т.В., Чулкова Ю.С., Карасев Д.В., Лебедева Н.П., Перепелкин К.Е., Гребенников С.Ф. Протонная магнитная релаксация в ароматических полиамидах при сорбции водяного пара. Журнал физической химии. 2009. Т. 83. № 7. С. 1346-1351. 
A well-known method of obtaining polymer composite materials of tribotechnical purposes is the introduction of antifriction layered lubricants (graphite powder, molybdenum disulfide, shungite, etc.) into the polymer matrix. However, the authors ${ }^{5}$ showed that the use of antifriction fillers leads to a significant reduction in the strength and formation of pores in the volume of the polymer that reduces the performance characteristics of PCM. All this makes it impossible to use these polymer composite materials in heavy-loaded friction units. The use of organic fibers allows the simultaneous improvement of tribological characteristics (reduction of friction coefficient and intensity of linear wear) and increase in the strength characteristics of materials, because there is good adhesion between the binder and filler and achievement of isotropy of properties. Tribological compounds, in which the parts with OP based on phenylone are used, have a number of advantages when working in chemically active environments. In some cases, the service life of the parts of devices of the chemical industry that work in the solutions of caustic soda and hydrochloric acid, chlorobenzene and ethylbenzene (sliding bearings, end seals, thrust bearings, etc.) is superior to the service life of the parts made of such traditional materials as cast iron, babbitt, stainless and the number of well-known composites of tribotechnical purposes.

Such heat-resistant organic fibers as polyoxadiazole (Oxalon, manufactured by "Svitlogorsk Khimvolokno", Belarus), polyarylene (Lola, All-Russian Research Institute of Polymer Fibers (VNDIPV), Russia) and polysulfonamide (Tanlon T700, manufactured by Shanghai Tanlon Fiber Co., China) were used for creation of OP of tribotechnical purposes. Its distinctive feature among other OF is that they are characterized by simplicity of synthesis and cheap production.

Phthalic acids and hydrazine sulfate are used as monomers, and sulfuric acid and oleum are used as solvents to obtain Oxalon fiber; all these materials are available and cheap mass-produced products. The synthesis of the polymer is carried out in one stage, by polycondensation, on conventional equipment for the production of chemical fibers. It proceeds almost without emissions of harmful substances into the atmosphere, according to the following reaction:

5 Катаева В.М., Попова В.А., Сажина Б.И. Справочник по пластическим массам. Москва : Химия, 1975. 568 с. 


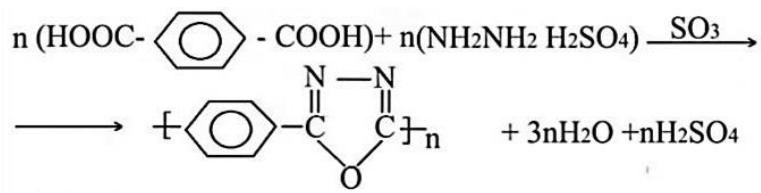

The main advantages of Oxalon organic fiber in comparison with other heat-resistant synthetic fiber are the availability and cheapness of initial materials, simplicity of method of synthesis and formation of fiber, high resistance to elevated temperatures (the loss of strength at the temperature of $573 \mathrm{~K}$ was $50 \%$ for 700 hours) and fire resistance.

Heat- and fire-resistant Lola fiber from heterocyclic polyarylene of stair structure is received by wet molding from sulfuric acid solutions (V.I. Terenin, A.I. Koretska, A.V. Volokhin). There is the foreign analog of Lola fiber. It is an American BBB fiber made of polyarylene. It is synthesized according to the following scheme:<smiles>Cc1ccc2c(c1)nc(-c1ccc(-c3nc4ccc(C)cc4n3-c3ccc(N)c(N)c3)c3c(C)ccc(C(=O)O)c13)n2OC(=O)c1ccc(C)c(N)c1</smiles>

Organic fiber Tanlon T700 is characterized by high values of thermal, corrosion and chemical resistance. It is obtained by wet molding from a spinning solution.

Preparation of organoplastics based on phenylone aromatic polyamide, containing 5-20 mass\% of OF (Oxalon, Lola, Tanlon), was carried out by dry mixing in an apparatus with a rotating electromagnetic field $(0.12 \mathrm{~T})$ using ferromagnetic particles that were removed from the prepared composition by magnetic separation ${ }^{6}$. The technology of reinforcing in the electromagnetic field, in contrast to the known method of obtaining composite materials in a solution of sulfuric acid, allows to obtain a composite with a uniform distribution of the filler in the polymer matrix. At the same time the duration of the process reduces. In addition, the use of this technique also increases the environmental safety compared to the method of obtaining PCM in a solution of sulfuric acid. This is explained by the fact that sulfuric acid is one of the aggressive chemicals, the use of which is

${ }^{6}$ Tomina A.-M., Yeriomina Ye., Terenin V. Designing the organoplastics based on aromatic polyamide, study of their operational properties and applicability. Eastern-European Journal of Enterprise Technologies. 2019. Vol. 100. No. 4(12). Pp. 16-22. DOI: 10.15587/1729-4061.2019.176698. 
accompanied by damage to the respiratory tract, skin, and mucous membranes that causes the difficulty of breathing, coughing, and such diseases as laryngitis, tracheitis, bronchitis.

The distribution of organic fibers in the polymer matrix is shown in Fig. 1.

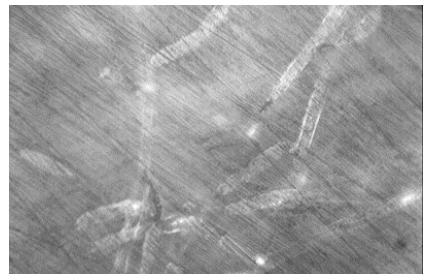

a

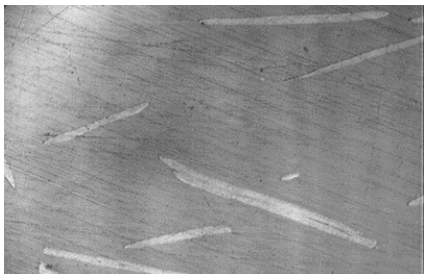

b

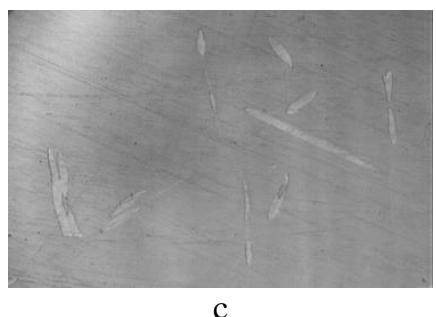

Fig. 1. Microstructure $(\times 150)$ of the distribution of 5 mass $\%$ of organic fiber: Oxalon (a), Lola (b), Tanlon (c) in a polymer matrix

The effect of mixing time of the compositions $(t=10-60 \mathrm{~s})$ in a rotating electromagnetic field and the length of ferromagnetic particles $(\mathrm{l}=5-30 \mathrm{~mm})$ was studied to achieve a uniform distribution of organic fiber in the polymer matrix. It has been experimentally found out that an effective uniform distribution can be achieved at $\mathrm{t}=30 \mathrm{~s}$ and $\mathrm{l}=10 \mathrm{~mm}$. Increasing the mixing time and the length of ferromagnetic particles to critical ones is accompanied by the formation of OF agglomerates that leads to anisotropy of the properties of composites. The formation of finished products was carried out by compression molding.

Friction and wear of the OP according to the "disk-finger" scheme were carried out on a disk friction machine with a load of $0.6 \mathrm{MPa}$, a sliding speed of $1 \mathrm{~m} / \mathrm{s}$. The accuracy of friction force measurement is $\pm 5 \%$. The wear of the samples was determined by weighing method on VLR-200 analytical scales (GOST (State Standard) 24104-80) with an accuracy of $0.0001 \mathrm{~g}$, a sliding speed of $1 \mathrm{~m} / \mathrm{s}$. Tribotechnical characteristics in the conditions of friction without lubrication according to the "disk-pad" scheme were determined on the SMC-2 friction machine at a load of $1 \mathrm{MPa}$, a sliding 
speed of $1 \mathrm{~m} / \mathrm{s}$. Steel $45(45-48 \mathrm{HRC}, \mathrm{Ra}=0.32 \mu \mathrm{m})$ was used as a counterbody. The intensity of linear wear $I_{h}$ was taken as the main engineering characteristic of the wear process.

Research of materials with regard to abrasive wear by rigidly fixed abrasive particles (dispersion of a skin was 40-60 microns) was carried out on the Hecker experimental machine. The sample (diameter and height was $15 \mathrm{~mm}$ ) was rotated around the axis of the moving cylinder under a load of $10 \pm 0.2 \mathrm{~N}$, and moved towards the skin with a clean surface.

The depth of abrasion tracks (surface roughness, $R_{a}, \mu \mathrm{m}$ ) of the initial polymer and organoplastics based on it was determined using 170621 profilometer by a sharp and hard needle (probe). It was moving along the test surface to copy all its roughness. The friction surfaces of the unfilled polymer and organoplastics based on it were studied using NEOPHOT32 optical microscope.

Measurement of the microhardness of the initial polymer and organoplastics based on it was performed on PMT-3M microhardness tester. The tests were conducted at room temperature by Vickers method with the indenter shaped as a regular four-sided pyramid with an apex angle of $136^{\circ}$. The investigated flat surface was carefully polished by means of diamond pastes until microscopic roughness and scratches disappeared. A measure of the hardness in this method is the surface area of the indentation. The study allowed to obtain the characteristic of reinforced plastics in its micro volumes at the matrix organoplastics. The load on the stem of the pyramid was $20 \mathrm{~g}$.

\section{Results of the research}

The results of tribotechnical characteristics of organoplastics under friction conditions without lubrication indicate that the use of Lola, Oxalon and Tanlon organic fibers (Table 1) is a promising way to improve the tribological properties of the initial polymer.

It was found that the most effective influence on improving the tribological properties of the base polymer is the use of Lola and Oxalon organic fibers. On the basis of the results of tribological studies according to the "disk-finger" and "disk-pad" schemes, it was found that the introduction of polyoxadiazole and polyarylene fiber leads to a decrease in the coefficient of friction and the intensity of linear wear of the initial material by $1.3-2$ and 5-12 times and 4.8-6.5 and 1.4-2.3 times, respectively. These results can be explained as follows.

A boundary layer (transfer film) appears in the process of friction of the $\mathrm{OP}$ on the steel disk; that performs several important functions during 
friction. On the one hand, it prevents direct contact of polymer roughness (cracks, microrelief) and protects the surface layers of friction bodies, significantly reduces the adhesion of OP to the counterbody ${ }^{7}$. On the other hand, the transfer film ensures the stability of the process of friction and wear due to the self-organization of the structure of the surface layers of the tribopair. In this case, the individual particles formed during the wear process and not transferred to the transfer film are removed from the friction zone by the tangential component of the sliding speed. Because of these factors, the time of existence of a friction connection between the counterbody and the sample is reduced ${ }^{8}$. The coefficient of friction reduces additionally.

Table 1

\section{The effect of organic fiber content} on the tribological properties of phenylone C-1

\begin{tabular}{|c|c|c|c|c|}
\hline \multirow[b]{2}{*}{$\begin{array}{l}\text { The content } \\
\text { of the fiber, } \\
\text { mass \% }\end{array}$} & \multicolumn{2}{|c|}{ "Disk-pad" scheme } & \multicolumn{2}{|c|}{ "Disk-finger" scheme } \\
\hline & $\begin{array}{c}\text { Friction } \\
\text { coefficient, } f\end{array}$ & $\begin{array}{c}\text { Intensity of } \\
\text { linear wear, } \\
I_{h} \cdot 10^{-8} \\
\end{array}$ & $\begin{array}{c}\text { Friction } \\
\text { coefficient, } f\end{array}$ & $\begin{array}{c}\text { Intensity of } \\
\text { linear wear, } \\
I_{h} \cdot 10^{-8}\end{array}$ \\
\hline- & 0.42 & 7.43 & 0.51 & 3.85 \\
\hline \multicolumn{5}{|c|}{ Oxalon } \\
\hline 5 & 0.32 & 2.90 & 0.3 & 1.9 \\
\hline 10 & 0.31 & 1.89 & 0.29 & 0.98 \\
\hline 15 & 0.3 & 1.54 & 0.26 & 0,4 \\
\hline 20 & 0.35 & 1.58 & 0.25 & 0.33 \\
\hline \multicolumn{5}{|c|}{ Lola } \\
\hline 5 & 0.25 & 4.18 & 0.3 & 2.9 \\
\hline 10 & 0.2 & 1.35 & 0.26 & 1.5 \\
\hline 15 & 0.18 & 1.2 & 0.25 & 1.05 \\
\hline 20 & 0.18 & 1.15 & 0.26 & 0.94 \\
\hline \multicolumn{5}{|c|}{ Tanlon } \\
\hline 5 & 0.37 & 6.91 & 0.46 & 3.55 \\
\hline 10 & 0.33 & 5.98 & 0.453 & 3.4 \\
\hline 15 & 0.32 & 6.11 & 0.45 & 3.25 \\
\hline 20 & 0.32 & 6.16 & 0.45 & 3.27 \\
\hline
\end{tabular}

${ }^{7}$ José A. Reglero Ruiz, Miriam Trigo-López, Félix C. García, José M. García. Functional Aromatic Polyamides. Polymers. 2017. No. 9. Pp. 1-44. DOI: $10.3390 /$ polym 9090414 .

8 Краснов А.П., Рашкован И.А., Афоничева О.В., Казаков М.Е., Кулачинская О.Б., Виноградова О.В., Баженова В.Б., Широков В.А., Адериха В.Н. Трение и изнашивание углеродопластов на основе полиамидов различного химического строения. Трение и износ. 2006. Т. 27. № 5. С. 527-534. 
Also in addition, an abrupt decrease in the wear of the OP in comparison with initial polymer occurs due to the fact that the fiber, concentrating on the friction surface, forms cluster structures with binder fragments (that, in a crude approximation, can represented as concentration of fibers that interact through film layers of the matrix environment) that play the role of a protective screen which localizes shear deformations in its volume and prevents the destruction of the surface layer of organoplastics ${ }^{9}$. Thus, when the initial polymer is under friction conditions, deep ploughing furrows are formed on its surface $\left(R_{a}=0.47 \mu \mathrm{m}\right)$ - the roughness of the harder surface (disk) ploughs the softer one (polymer) forming a friction path. According to the Bowden and Tabor sliding friction model, resistance to ploughing causes a force that contributes to the friction force, so-called ploughing component of friction force that is accompanied by adhesion, that is, an adhesive-wear mechanism is observed between the sample and steel counterbody adhesive-fatigue mechanism of wear ${ }^{10}$.

Reduction of the adhesive component of the force (transition to the pseudoelastic wear mechanism) and roughness of organoplastic $\left(R_{a}=0.25 \mu \mathrm{m}\right)$, the surface becomes smoother) is accompanied by an increase in the actual contact area (Fig. 2). That is, it can be explained as follows: a small amount of wear products formed in the process friction is spread on the steel counterbody (particles of polymer matrix and shredded products of wear of organic fiber), and the other one is removed outside it. It should also be noted that when the "antifriction layer" spreads on the surface of the steel counterbody, the subsequent friction occurs according to the "polymer-polymer" scheme, and the counterbody is removed from the wear process.

Organoplastics with an effective filler content (15 mass\% of Oxalon and Lola. and 10 mass\% of Tanlon) were studied in the range of loads and speeds from 1.0 to $2.0 \mathrm{MPa}$ and from 0.5 to $1.5 \mathrm{~m} / \mathrm{s}$ according to the "disk-pad" scheme, respectively (Table 2).

It was found (Table 2) that when the load and sliding speed increase to $2.0 \mathrm{MPa}$ and $1.5 \mathrm{~m} / \mathrm{s}$, the formation of zones of gripping with the counterbody is observed that causes an abrupt increase in the intensity of linear wear and friction coefficient (see Fig. 2).

${ }^{9}$ Roberto Scaffaro, Andrea Maio. Influence of Oxidation Level of Graphene Oxide on the Mechanical Performance and Photo-Oxidation Resistance of a Polyamide 6. Polymers. 2019. Vol. 11. P. 857. DOI: 10.3390/polym11050857.

10 Садова О.Л., Кашицький В.П., Савчук П.П. Формування самоорганізованих структур у поверхневих шарах трибовиробів на основі епоксикомпозитів. Вісник Прикарпатського наччонального університету імені Василя Стефаника. Серія «Хімія». 2015. № 19. С. 13-23. 
Table 2

The influence of the friction mode on the tribotechnical characteristics of phenylone and organoplastics based on it

\begin{tabular}{|c|c|c|c|c|c|c|c|}
\hline \multicolumn{2}{|c|}{ Friction mode } & \multicolumn{2}{|c|}{ Intensity of wear, $\boldsymbol{I}_{\boldsymbol{h}} \cdot \mathbf{1 0}^{-\mathbf{7}}$} & \multicolumn{2}{c|}{ Friction coefficient, $\boldsymbol{f}$} \\
\hline $\begin{array}{c}\boldsymbol{v} \mathbf{\boldsymbol { m }} \\
\mathbf{m} / \mathbf{s}\end{array}$ & $\begin{array}{c}\boldsymbol{P}, \\
\mathbf{M P a}\end{array}$ & Oxalon & Lola & Tanlon & Oxalon & Lola & Tanlon \\
\hline \multirow{3}{*}{0.5} & 1.0 & 0.09 & 0.08 & 0.35 & 0.28 & 0.13 & 0.18 \\
\cline { 2 - 9 } & 1.5 & 0.16 & 0.42 & 1.60 & 0.38 & 0.19 & 0.27 \\
\cline { 2 - 9 } & 2.0 & 0.33 & 0.54 & 3.30 & 0.40 & 0.34 & 0.33 \\
\hline \multirow{3}{*}{1.0} & 1.0 & 0.15 & 0.12 & 0.59 & 0.30 & 0.18 & 0.33 \\
\cline { 2 - 9 } & 1.5 & 0.42 & 0.43 & 6.25 & 0.40 & 0.25 & 0.35 \\
\cline { 2 - 8 } & 2.0 & 0.72 & 0.59 & 7.68 & 0.42 & 0.40 & 0.40 \\
\hline \multirow{3}{*}{1.5} & 1.0 & 0.20 & 0.32 & 2.65 & 0.39 & 0.20 & 0.37 \\
\cline { 2 - 8 } & 1.5 & 0.70 & 0.52 & 7.32 & 0.42 & 0.30 & 0.38 \\
\cline { 2 - 8 } & 2,0 & 1.62 & 0.65 & 9.20 & 0.43 & 0.47 & 0.43 \\
\hline
\end{tabular}

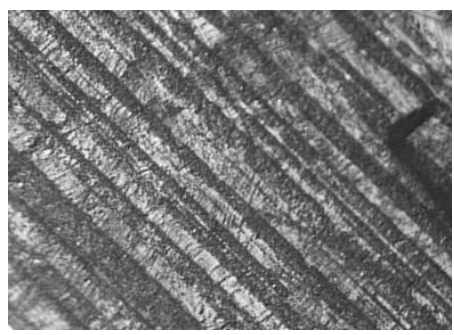

a

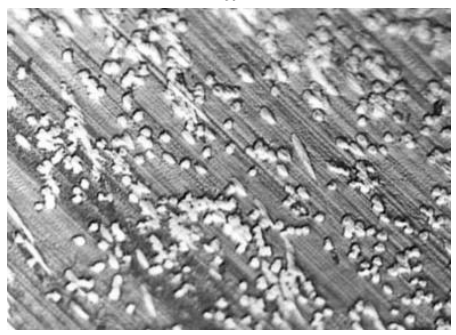

$\mathrm{c}$

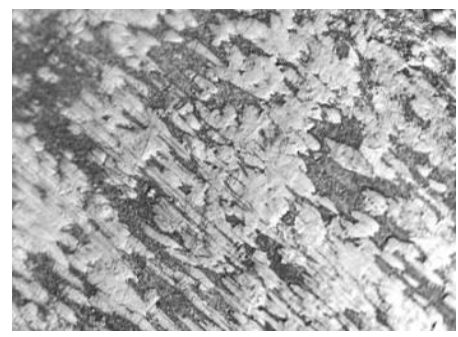

b

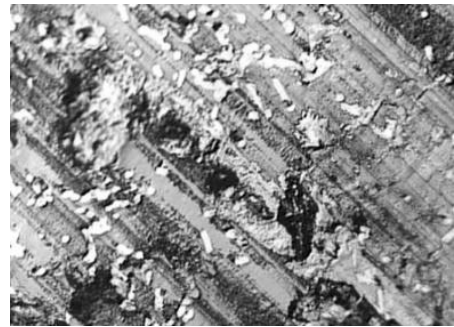

d

Fig. 2. Microstructure $(\times 150)$ of the initial polymer (a) and organoplastics containing Oxalon fiber (15mass\%, b) and Lola (15mass\%, c, d) according to the "disk-pad" scheme in the friction mode: $P=1.0 \mathrm{MPa}$ and $v=1.0 \mathrm{~m} / \mathrm{s}(\mathrm{a}, \mathrm{b}, \mathrm{c})$ and $P=2.0 \mathrm{MPa}$ and $v=1.5 \mathrm{~m} / \mathrm{s}(\mathrm{d})$

The test results regarding the friction of organoplastics on hard abrasive particles are given in Table. 3. It can be seen that the reinforcement of the 
original polymer with heat-resistant organic fibers is a promising way to increase the abrasive wear resistance of the initial polymer by $22-56 \%{ }^{11}$.

Table 3

The indicator of abrasion of organoplastics based on phenylone

\begin{tabular}{|c|c|c|c|}
\hline \multirow{2}{*}{$\begin{array}{l}\text { The content of } \\
\text { the fiber, mass \% }\end{array}$} & \multicolumn{3}{|c|}{ The indicator of abrasion, $V_{i}^{3}, \mathrm{~mm}^{3} / \mathrm{m}$} \\
\hline & Oxalon & Lola & Tanlon \\
\hline- & \multicolumn{3}{|c|}{1.88} \\
\hline 5 & 1.60 & 1.16 & 1.32 \\
\hline 10 & 1.40 & 0.83 & 1.10 \\
\hline 15 & 1.49 & 0.83 & 1.39 \\
\hline 20 & 1.73 & 1.25 & 1.47 \\
\hline
\end{tabular}

This conclusion is based on a significant reduction in ploughing furrows in comparison with phenylone (see Fig. 3).
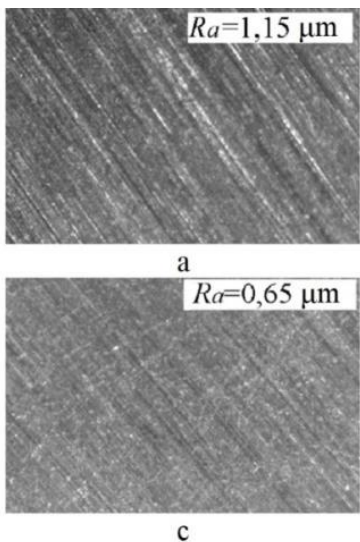
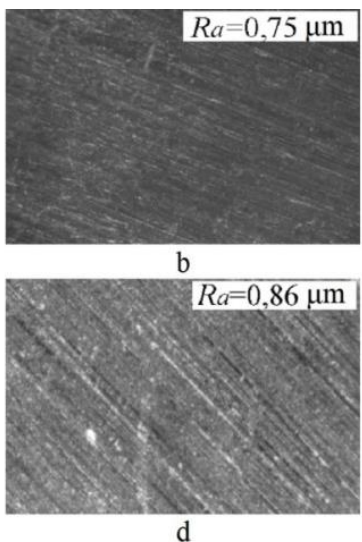

Fig. 3. Microstructure $(\times 180)$ of the friction surface of phenylone C-1 (a) and organoplastics based on it containing Oxalon lon fiber (10 mass \%, b), Lola (15 mass \%, c) and Tanlon (10 mass\%, d)

This is due to the strengthening of the polymer matrix (microhardness increases by $20 \%$ on the average, see Fig. 4) during the introduction of organic fibers (Oxalon, Lola and Tanlon), as a result furrows of ploughing

11 Зуев Ю.С. Разрушение полимеров под действием агрессивных сред. Москва : Химия, 1972. 229 с. 
organoplastics reduce and the development of destructive processes on the friction surface inhibits ${ }^{12}$. That increases the wear resistance of OP that is confirmed by images of the microstructure shown in Fig. 3.

The improvement of tribotechnical characteristics occurs due to the ordering of the binder structure ${ }^{13}$. The presence of this structure is confirmed by electron microscopic studies of brittle fracture surfaces, developed organoplastics and pure phenylone. The obtained results make it possible to identify differences in the morphology of the destruction of composites and the initial phenylone; that is shown in Fig. 5. Let us first characterize the fracture structure of the phenylone aromatic polyamide.

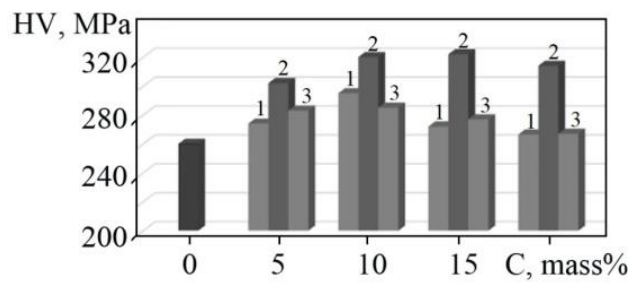

\section{Fig. 4. The value of the microhardness of the initial polymer and organoplastics based on it and containing: polyoxadiazole (1), polyarylene (2) and polysulfonamide (3) fiber}

Fig. 5 shows that the surface has a cellular structure that is observed when the destruction of the material is carried out outside the components of the structure of the matrix. In this case, the structural elements of phenylone are globules. The mutual positioning of individual sections of the chain macromolecule inside the globule is usually random and almost any polymer, which has a globular structure, is in an amorphous state. Fracture of the polymer takes a transglobular shape with the introduction of Lola fiber (Fig. 5, b): that is, the filler acts as a dislocation that prevents the macromolecules of phenylone from curling into a globular shape. It should be noted that this phenomenon is observed not because of the difference in strength characteristics of the

12 Петрова П.Н., Гоголева О.В., Охлопкова А.А. Разработка самосмазывающихся материалов на основе политетрафторэтилена. Электронный научный журнал «Нефтегазовое дело». 2011. № 2. С. 291-297.

${ }_{13}$ Каргин В.А. Слонимский Г.Л., Соголова Т.И Связь надмолекулярной структуры с механическими свойствами полимеров. 22nd Annual Technical Conference : Тезисы докл. 1966. № 12. Montreal. С. 43. 
polymer matrix and OF, but due to the chemical interaction between them. This conclusion is made because in the case of brittle fracture, the fibers are stretched, but not pulled out of the polymer matrix, and the destruction of organoplastics occurs through cracks that occur in the volume of the matrix that indicates the presence of adhesion.

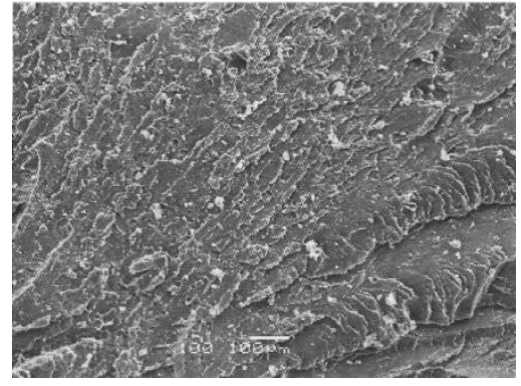

a

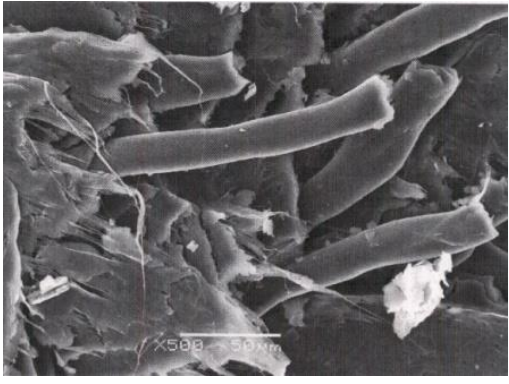

b

Fig. 5. Microstructure of brittle fracture of the base polymer (a) and organoplastic (b) based on it with 15 mass\% content of Lola fiber

\section{Development of recommendations for the use of organoplastics}

It is obvious that reliable operation of agricultural equipment and looms is inextricably linked with the efficiency of tribological joints (in $90 \%$ of cases), because in the process of their malfunction a significant economic resource is spent for their repair. Positive results of laboratory researches of the developed organoplastics allowed to pass to their industrial tests in sliding friction units of agricultural and textile machinery.

Agricultural machinery. Apparently, high efficiency of plain bearings of modern agricultural machinery, which is operated in Ukraine, requires the selection of materials with high wear resistance. Because wear is one of the main damaging processes that reduces the efficiency of the equipment. The tribological researches were carried out and positive results were obtained. These results allow to recommend the developed organoplastics as a material of tribotechnical purpose. It is proposed to manufacture the parts of friction units of machines working in difficult conditions (increased dust, the influence of abrasive particles) of agricultural machinery in order to increase their reliability and durability, reduce weight (almost 5 times), reduce material consumption and complexity of their manufacture, improve working conditions (due to self-lubrication). 
Stable operation of the RKS-6A root-harvesting machine is guaranteed by the automatic machine of driving on lines. The effective work of it, in turn, is guaranteed by the serviceability of parallelogram suspensions that use No. 943/20needle bearings. Only nigrol lubricant is used as a lubricant for stable operation of plain bearings. The use of other lubricants leads to jamming. However, during the operation of the machine there is also frequent jamming of the driving machine as a result of dust, soil, dirt, moisture in the needle bearings. Taking into account the above, needle bearings No. 943/20 (GOST (State Standard) 4060-60) were replaced with composite made of organoplastics with an effective 10 mass \% content of Oxalon. Thus, 600 pieces of experimental bearings have been successfully tested. Bearings, which were made from OP, worked flawlessly in conditions of high abrasion and friction without lubrication in contrast to the serial ones. It should be noted that during the period of operation, there were no failures in the operation of automatic machines equipped with composite bearings.

Taking into the account that the introduction of organic Oxalon fiber increases the wear resistance of the initial polymer 12 times, comparative stand studies of the eyes of the auger finger made of OP and bronze were carried out. The tests were performed on a special stand for $600 \mathrm{~h}$; that simulated the operation of the part in conditions as close as possible to the real operating conditions of the part with a specific load of $\mathrm{P}=0.29 \mathrm{MPa}$ and a sliding speed of $v=0.4 \mathrm{~m} / \mathrm{s}$. The test results indicate that the eyes of the auger, which are made of the proposed composite, meet the operating conditions of the harvester and are characterized by low wear. Positive results of stand researches allow to recommend eyes from OP for field researches. It is found that in the process of the tests on Dnipropetrovsk and Magdalinovsky districts farms that harvesters, which have worked 190-238 hectares and grinded 320-523 tons, wear of eyes from OP was $0.1-0.23$ $\mathrm{mm}$, while the wear of serial ones was $0.4-0.57 \mathrm{~mm}$.

Tribological connections of SUPO-6-01 and C3-3,6 vegetable seeders work in direct contact with ground; as a result, soil particles get inside them and cause deformation and intensive wear of details. As a result, they jam. That leads to equipment downtime and subsequent repairs leading to major material damage. Taking into account the rapid failure of serial ball bearings due to aggressive operating conditions, as well as the impossibility of using lubricants due to high dust in the area of the friction unit, it was advisable to test plain bearings from the developed OP. In order to increase the working life of the friction units of the SUPO-6-01 and C3-3,6 seeders for K-V F "APEX" LLC, comparative stand tests of serial balls and the ones from the proposed organoplastics with a filler content of 10 mass $\%$ of Oxalon fiber 
were carried out. Ball bearings No. 36206 and No. 180503 for the friction units of the fan of the SUPO-6-01 vegetable seeder of exact seeding and double-disc seed drill of the C3-3,6 grain seeder were selected as the object of the study. According to the test report, the experimental plain bearings operated under friction conditions without lubrication for 380 hours and remained suitable for further operation (average linear wear was $0.09 \mathrm{~mm}$ ). The plain bearings of the C3-3.6 double-disc seed drill from OP worked twice as much as the serial ones. The results of micrometering of the inner surface of plain bearings indicate that their maximum linear wear was $0.1 \mathrm{~mm}$, while for serial ball bearings made of cermets it was $0.32 \mathrm{~mm}$.

Textile machinery. Today, Ukrainian textile industry is one of the most important branches of light industry. In the future, it has a great potential to increase production through the expansion of the domestic market and exports. For example, Dnipropetrovsk region was among the five leaders of the textile industry of Ukraine according to the regional rating of light industry production in 2016.

However, it lost the lead in subsequent years. There are several reasons restricting the development of the textile industry. The main one is the lack of reliability of the equipment connected with the failure of looms due to wear of plain bearings under the influence of friction. In addition, the obsolescence of domestic weaving equipment also reduces the pace of production of quality products. As a result, most Ukrainian companies including Dnipropetrovsk region abandon domestic equipment and use such expensive imported equipment as Tongda TD (China), Toyota Industries, Tsudakoma (Japan), Picanol (Belgium), Dornier (Germany), Promatech (Italy), Schacht (USA). It should be noted that the failure of imported equipment leads to even greater losses, because repairs and new parts cost a lot. This increases the downtime of the equipment, because it is difficult to find a highly qualified repairman, and the waiting time, when ordering new parts for friction units, can reach about one month. The combination of these factors leads to the fact that the weaving enterprises of Ukraine suffer from significant material losses, their products rise in value, and production decreases.

The solution to this problem can be the modernization of friction units of domestic and imported equipment through the use of fibrous PCM that will increase the wear resistance of tribounits of textile machinery. Many studies have shown that the replacement of serial metal parts with the OP leads to increased reliability of friction units (up to 1.5 times), working life (up to 3 times) and efficiency (reduction of costs by $40 \%$ in the manufacture of parts), while reducing preventive measures to maintain their stable operation. 
Thus, the replacement of traditional metallic materials with polymeric ones in the friction units of looms will allow the manufacturer to increase the reliability of equipment and service life, increase production and economic feasibility, reduce the cost of final products.

The object of research is the friction units of the drive mechanism of the felting loom by Tongda TD company (China), installed at the "SYNERGY" NGO (Kyiv, Ukraine) (Fig. 6).

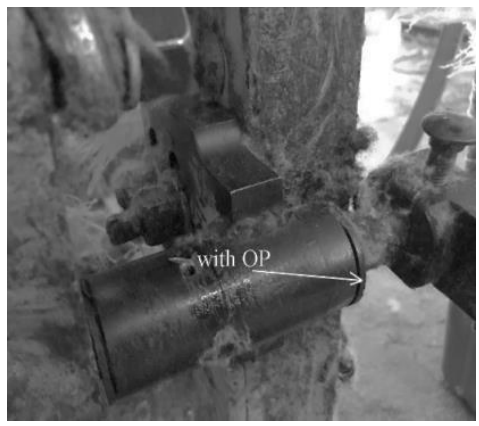

\section{Fig.6. Friction unit of the drive mechanism of the doffer of weaving machine Tongda TD from organoplastic}

These units work in the conditions of friction without lubrication at the increased vibrations and pollution. At the same time, the serial units of the drive mechanism of the felting loom, which are made of cast iron, are operational only for 6336 hours. Experimental parts from OP (15 mass\% of Lola fiber), which were installed to replace the serial rolling bearings, worked for 8640 hours. During production tests no deviations from the norm of experimental units were detected. After all the experiments, the expediency of using OP instead of traditional metals is confirmed.

Experimental plain bearings with an effective content of Oxalon fibers (10 mass\%) were put in the mechanisms of the JACOB MULLER Varitex loom to determine the possibility of using organoplastic in heavy-loaded friction units. The proposed bearings worked flawlessly for 8640 hours and then were left for further operation, while the serial NK2012 and NK6624901 steel bearings in these units failed after 4320 hours. Based on results of the tests of plain bearings made of organoplastics, it can be recommended to introduce them into serial production and use in VERITEX LLC.

Stand tests of organoplastic (10 mass\% of Tanlon fiber) were carried out on the stand that simulates the operation of the friction unit of the loom. It is shown that the bearings made of the proposed material meet the operating 
conditions of the machine and are characterized by less wear in comparison to the serial ones. Positive results of stand researches allowed to recommend bearings from OP for following production tests ${ }^{14}$.

\section{CONCLUSIONS}

In general, the analysis of tribological properties of the developed organoplastics shows that the use of organic fibers (Oxalon, Lola and Tanlon) as a filler is a promising way to improve performance (reduce wear and friction) of polymeric materials. It is shown that the introduction of fillers leads to improved wear resistance of phenylone in friction conditions without lubrication from 5 to 12 times depending on the test scheme and the nature of the fiber. In addition, it was also that the introduction of organic fibers increases the tribotechnical indicators of the initial polymer in conditions of friction on hard abrasive particles by an average of $40 \%$.

Production tests have confirmed the feasibility and effectiveness of using the developed OP as tribotechnical materials for parts of moving joints of agricultural machinery and looms operating in conditions of friction without lubrication, increased dust and the action of abrasive particles. It is found that the introduction of the developed bearings with OP in the friction units of the RKS-6A root harvester allowed to increase the durability of the friction unit up to 3 times on average while reducing maintenance costs. Experimental parts made of organoplastics (15 mass \% of Lola fiber), which were put in the friction unit of the drive mechanism of the Tongda TD felted loom, proved to be more efficient than the serial ones. While serial parts fail due to catastrophic wear in one year, the developed parts did not show any deviations from the norm and worked for more than a year. Stand tests of the head of the reaper auger and the sliding bearings of the vegetable drills have shown that the organoplastics are 2 times superior to the serial materials of tribotechnical purpose. Experimental parts made of organoplastics (10 mass \% of Oxalon fiber), which were put in the friction mechanism of the JACOB MULLER Varitex loom, worked flawlessly for a year (8640 hours) and were left for further use.

\section{SUMMARY}

The influence of organic (polyoxadiase, polyarylene and polysulfonamide) fibers on the tribological properties of phenylone

${ }^{14}$ Томіна А.-М.В. Встановлення закономірностей впливу органічних волокон на властивості та структуру ароматичного поліаміду фенілон : дис. на здобуття вченого ступеня канд. техн. наук : 05.02.01. Кам'янське, 2019. 230 с. 
aromatic polyamide is considered in the article. It is found that the developed organoplastics surpass the base polymer both in terms of wear resistance under friction without lubrication from 5 to 12 times depending on the test scheme and the nature of the fiber and in hard abrasive particles by $40 \%$. The expediency, profitability and efficiency of using the developed organoplastics as materials of tribotechnical purpose for details of units of sliding friction of agricultural and textile machinery are confirmed.

\section{REFERENCES}

1. Кулагина Г.С., Коробова А.В., Ильичев А.В., Железина Г.Ф. Физические и физико-механические свойства антифрикционного органопластика на основе комбинированного тканого наполнителя и эпоксидного связующего. Труды ВИАМ. 2017. Т. 58. № 10. С. 69-78.

2. Лупкин Б.В., Мамлюк О.В., Драник А.И., Касс А.Л. Влияние технологических параметров процесса сверления композиционных материалов на прочность. Открытые информационные $u$ компьютерные интегрированные технологии. 2016. № 71. С. 125-135.

3. Набережна О.О. Розробка та дослідження властивостей самоармованих органопластиків на основі термостійких ароматичних поліамідів : дис. на здобуття вченого ступеня канд. техн. наук : 05.02.01. Луцьк, 2017. 205 с.

4. Смотрина Т.В., Чулкова Ю.С., Карасев Д.В., Лебедева Н.П., Перепелкин К.Е., Гребенников С.Ф. Протонная магнитная релаксация в ароматических полиамидах при сорбции водяного пара. Журнал физической химии. 2009. Т. 83. № 7. С.1346-1351.

5. Катаева В.М., Попова В.А., Сажина Б.И. Справочник по пластическим массам. Москва : Химия, 1975. 568 с.

6. Tomina A.-M., Yeriomina Ye., Terenin V. Designing the organoplastics based on aromatic polyamide, study of their operational properties and applicability. Eastern-European Journal of Enterprise Technologies. 2019. Vol. 100. No. 4(12). Pp. 16-22. DOI: $10.15587 / 1729-4061.2019 .176698$.

7. José A. Reglero Ruiz, Miriam Trigo-López, Félix C. García, José M. García Functional Aromatic Polyamides. Polymers. 2017. No. 9. Pp. 1-44. DOI: 10.3390/polym9090414.

8. Краснов А.П., Рашкован И.А., Афоничева О.В., Казаков М.Е., Кулачинская О.Б., Виноградова О.В., Баженова В.Б., Широков В.А., Адериха В.Н. Трение и изнашивание углеродопластов на основе полиамидов различного химического строения. Трение и износ. 2006. T. 27. № 5. C. 527-534. 
9. Roberto Scaffaro, Andrea Maio. Influence of Oxidation Level of Graphene Oxide on the Mechanical Performance and Photo-Oxidation Resistance of a Polyamide 6. Polymers. 2019. Vol. 11. P. 857. DOI: $10.3390 /$ polym1 1050857.

10.Садова О.Л., Кашицький В.П., Савчук П.П. Формування самоорганізованих структур у поверхневих шарах трибовиробів на основі епоксикомпозитів. Вісник Прикарпатського національного університету імені Василя Стефаника. Серія «Хімія». 2015. № 19. C. 13-23.

11.Зуев Ю.С. Разрушение полимеров под действием агрессивных сред. Москва : Химия, 1972. 229 с.

12.Петрова П.Н., Гоголева О.В., Охлопкова А.А. Разработка самосмазывающихся материалов на основе политетрафторэтилена. Электронный научный журнал «Нефтегазовое дело». 2011. № 2. C. 291-297.

13.Каргин В.А., Слонимский Г.Л., Соголова Т.И Связь надмолекулярной структуры с механическими свойствами полимеров. 22nd Annual Technical Conference : Тезисы докл. 1966. № 12. Montreal. C. 43.

14.Томіна А.-М.В. Встановлення закономірностей впливу органічних волокон на властивості та структуру ароматичного поліаміду фенілон : дис. на здобуття вченого ступеня канд. техн. наук : 05.02.01.

\section{Information about authors:} Tomina A.-M. V., Candidate of Technical Sciences, Senior Lecturer at the Department of Condensed Matter Physics Dniprovsk State Technical University 2, Dniprobudivska str., Kamyanske, Dnipropetrovsk region, 51918, Ukraine

Buria O. I., Candidate of Technical Sciences, Professor 